\title{
Strategic Environmental Assessment (SEA) and its Practice Particularly With Reference to Nepal
}

\author{
Ram Khadka* \\ Pokhara University, Nepal
}

Submission: July 01, 2017; Published: August 23, 2017

*Corresponding author: Ram Khadka, Professor of Environmental management at SchEMS Pokhara University, Nepal, Email: ram29765@gmail.com

\section{Introduction}

Environmental Impact Assessment (EIA) is a tool being used to ensure environmentally sound and sustainable project implementation. Initially it was used in the USA in 1969 and recognizing its effectiveness in curbing of the environmental effects of development projects, its application was adopted by the other countries of the world. It was endorsed by the 1972 Stockholm conference, WECD1989, Rio Earth Summit 1992 and further reinforced by 2002 Johannesburg conference. Accordingly, Nepal has made its application mandatory by the enforcement of Environmental Protection Act and Regulation 1997 and a Ministry of Environment was established. Its application has now crossed over to 16 years, but benefits of its application have not yet been documented because of the absence of recorded information, of monitoring and follow up actions. So it has largely failed to demonstrate its creditable value in the support of sustainable development. The country papers on EIA applications in South Asian countries were presented in South Asian Environmental Assessment Conference held in Islamabad, Pakistan on December 2013 and it was revealed that, there are confusion in the current practice of EIA, caused primarily by

I. The inadequacy of trained human resources,

II. Absence of a system of monitoring and follow-up actions and

III. Dealing with a mixed of strategic and project level issues to be address during the project level implementation [1].

\section{Education Skilled and Professional Training and Accreditation}

EIA is now slowly main streamed into the national project planning processes; however failing of understanding of its complexities by the EIA administrator, policy makers, planner, decision makers and proponents has made its application ineffective and is not able to reap its benefits as it was envisaged. Training on EIAs has been organized by a number of institutions locally and internationally for professionals, planners, decision makers and practitioners, however such training programs are organized in mostly in sporadic manner; training for practitioners and implementers are also required to be organized in regular basis in order to update and sharing of the knowledge from the experiences . Currently University curriculum are being designed to include EIA in Environmental Science and Engineering courses in order to cater, more experts to be made available in the future. At present, the human resources in EIA are not fully equipped with an appropriate skills and the practice of undertaking EIA at the project level. Absence of experts' accreditation system for conducting an EIA study has made low grade quality of reports and coping and pasting of the previous reports have became widespread. EIA is a cross-cutting and technical subject and it requires infusion of multiple disciplines; needing very careful analysis with valid justification of the all the disciplines and requires precise conclusions in order to make right decisions at different stages of project implementation. So EIA making is not a joke, it becomes extremely sensitive matter which has a long term consequences. An accreditation and regular training of the experts and the administrators are urgently required [2].

\section{Strategic Issues and Project Specific Impacts}

One of the major contributors in making EIA process inelegant is the mixing of strategic with project specific issues. Project specific issues are simple, emanating directly from the project construction; such as excavating the earth for construction purpose; establishment of temporary camp site for workforces, water pollution issues around the camp site etc while downstream water shortage, people's displacement, Biodiversity issues, land acquisition and settlement, air and water pollution, sanitation and waste disposals are strategic issues and these are not easy to address at the project level implementation and require policy plan and program interventions. At the project level, as for example, the excess materials of earth cutting can be disposed off at designated place, temporary workforce camp sites, and anything that has 
been damaged by project construction can be easily reinstated during and after project construction The current EIA attempts to address all of these issues (project and strategic level), so it is difficult to handle everything and the measures provided are not effective [3].

\section{Strategic Moves}

It is always imperative to examine long term consequence on the environment while formulating Policy, plan and program, Most of the strategic environmental issues that are likely to emanate in the process of formulation of Policy, Plan and Program (PPPs) are often addressed through Strategic Environmental Assessment (SEA). Cabinet decision becomes some time strategic action/policy/law that has immediate effects on the action proposed. Expansion of narrow road in Kathmandu and other municipalities of Nepal was an example of cabinet decision at strategic level albeit based on the existing law. Supreme Court decision has also become popular and effective for some immediate actions to be carried out. The decision of Nepal's Supreme Court of 2007 to control pollution from brick factories in Bhaktapur and Kathmandu has provided provisions on the location of brick kilns and made a mandatory requirement to install pollution control devices. The famous interventions of the Delhi High Court on various Environmental problems in India such as banning of polluting industries around Taj Mahal in 1984, Ganga Water Pollution case, Vehicular Pollution case 1995, ground water pollution and depletion case 1995 were all taken over by the Supreme court of India and issued strategic directives to the government to act to control the adverse effect on the environment [4].

\section{Strategic Environmental Assessment (SEA)}

The cabinet decision and high court directives are often implemented where respective departments of government are ineffective and such decisions tend to solve the immediate problems and set out some customary actions; however it is not going to be a long term solution. The establishment of Strategic Environmental Assessment (SEA) system to examine a long term repercussion on the formulation of Policy, Plan and Program is considered to be the most effective ways to ameliorate the anticipated effects of their implementation.

However, to address environmental issues at a higher level of decisions, Environmental Assessment is being used, under the name of Strategic Environmental Assessment (SEA). SEA is considered as a forward looking process and it is believed that the cause of unsustainability is located at the "upstream" of the decision-making. Therefore, the use of SEA represents a promising means of addressing some of the major environmental issues at the initial stage of policy making, plan and program formulation [5].

\section{What Is Sea}

SEA is defined as "the formalized, systematic and comprehensive process of evaluating the environmental impacts of Policy, Plan and Program (PPPs) and proposing their alternatives. SEA, in other words, is the environmental and social assessment of Policies, Plans and Program (PPPs). The Policies, Plans, and Programs are generally described as "Strategic" and are not identical, and may require the application of different variations of SEA. PPPs may be sector-specific (e.g., transport, power development, mineral extraction), or spatial (e.g., national, local) [6].

In theory, PPPs are tiered; such as a policy provides frameworks for the establishment of plans; plan provides frameworks for programs; and a program leads to projects. In practice, these tires may not have any clear-cut distinctions. Therefore the environmental and social assessment for PPPs itself be tiered, so that the issues considered at the higher tier may not need to be reconsidered at the lower levels of tier.

\section{Why SEA}

1. Addressing the cause of environmental problems at their policy source, rather than just treating the symptoms of impacts at the later stage,

2. To identify cumulative effects recognizing these are best means to deal with regionally or programmatically rather than on project-by-project basis;

3. To examine an environmental implication of non project actions like trade, treaty, tranboudary issues, national budget etc, and

4. Streamline project level EIAs making it easier, not complicated, implementable and taking shorter time for approval and implementation (Figure 1).

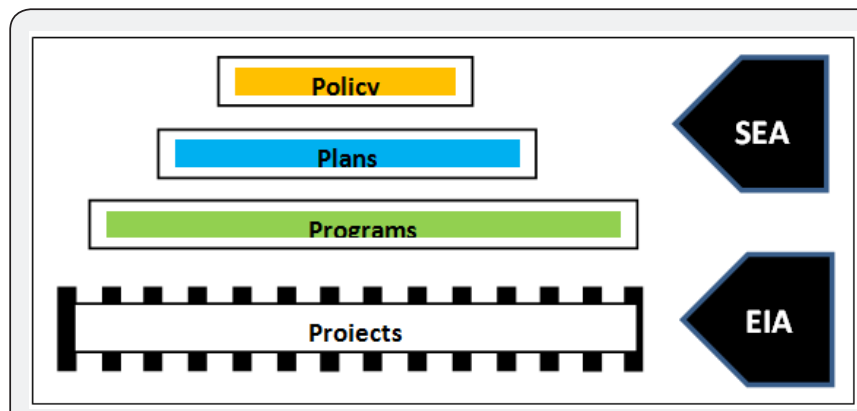

Figure 1: The hierarchy of environmental assessment OECD/ DAC 2006.

\section{SEA Methodology}

The key elements of a SEA process are formulation of policies, plans, and programs, can have profound effects on the environment in the form of possible positive or negative environmental issues and to be addressed by higher level decision-making. SEA is, in many ways, similar to environmental assessment for projects but SEA involves answering a series of questions during the development of a policy, plan, or program proposal. In addressing these questions, any potential negative impacts of the proposal can be identified and mitigated [7]. 


\section{Preliminary Scan (To Determine If There are Important Environmental Effects)}

It is not always initially known whether a policy, plan, or program will have important environmental effects. The process of quickly identifying potential significant environmental effects and whether they are positive or negative, is referred to as a «preliminary scan.» Normally it involves studies, discussion, meeting and brainstorm and consultation among stakeholders. A series of questions can be asked as part of the preliminary scan, to determine if an SEA is required; they are as follows:

1. What is the content of the proposal (policy, plan or program)?

2. Is the proposal concerned primarily with broad general direction(s)?

Or does it address or specifically include operational measures (e.g. Projects)?

3. What area or sector is targeted in the proposal?

a. Is the sector known to have, or is it likely to cause, environmental effects (e.g. Energy, transportation, housing, agriculture)?

b. Are there components which are likely to have cumulative or long-term consequences for the environment (e.g. Trade, industrial diversification, technology development)?

c. What environmental considerations are raised by the proposal? Does it appear likely to?

d. Initiate activities that will have direct or evident environmental impacts?

e. Arise broad environmental implications and/or issues that should be addressed?

f. have little or no environmental consequences?

The issues identified in Preliminary scan should be analyzed and may relate to direct impacts (e.g. Water pollution), the cause of impacts (e.g. Coal burning) or a general concern (e.g. Decrease in security). If there are no significant impacts, then the policy, plan and programs should move through the agencies for approval.

Table 1: A hypothetical example of sustainability framework.

\begin{tabular}{|c|c|c|c|}
\hline Parameters & Objectives & Criteria & Indicators \\
\hline Downstream flow & $\begin{array}{c}\text { Release adequate } \\
\text { amount of downstream } \\
\text { flow }\end{array}$ & Set the flow standards & $\begin{array}{c}\text { Measure the amount of } \\
\text { water released }\end{array}$ \\
\hline $\begin{array}{c}\text { Downstream water } \\
\text { pollution }\end{array}$ & $\begin{array}{c}\text { Reduction of pollution } \\
\text { level }\end{array}$ & $\begin{array}{c}\text { Pollution level within } \\
\text { national standards }\end{array}$ & $\begin{array}{c}\text { Measure pollution level } \\
\text { and ensure it is within } \\
\text { the national standards }\end{array}$ \\
\hline $\begin{array}{c}\text { Air pollution emission } \\
\text { may increase }\end{array}$ & $\begin{array}{c}\text { Reduction in air } \\
\text { pollution }\end{array}$ & $\begin{array}{c}\text { National standards for } \\
\text { air pollution emission }\end{array}$ & $\begin{array}{c}\text { Measure ambient } \\
\text { air pollution level to } \\
\text { ensure that it is within } \\
\text { the standard }\end{array}$ \\
\hline
\end{tabular}

\section{What is the Existing Situation? Baseline Information and Sustainability Parameters}

If the preliminary scanning has indicated likely effects on the environment such as in Physical, Biological and Socio economic parameters and categorized as adverse or beneficial. Next step is to analyze the existing situation of these resources and relate these on the findings of preliminary scanning and propose mitigation measures or enhancement measures. To accomplish this, existing environmental resources, institutions, level of public awareness legislation, policies, plans, programs, and multilateral environmental agreements should be analyzed in context of the issues. Most of this information will be obtained from secondary sources and consultation.

Sustainability parameters can be formulated to guide the outcome of the plan or program towards achieving the objectives for sustainability. These may be written in the form of principles or guidelines. The sustainability parameters should include recommendations on how the plan or program may address the environmental constraints and enhance the opportunities. These parameters may be quantitative (e.g. set levels for sulphur dioxide emissions), qualitative (e.g. promote the use of alternative low-sulphur sources of fuel in industry to minimize sulphur dioxide emissions) or spatially based (e.g. maps indicating zoning of activities including conditions for «no-go» areas).

The nature of the sustainability parameters would also be influenced by the level of the plan or program. For example, at a municipal level, the use of buffer zones and corridors may be necessary to ensure that marginal habitats are not lost. However, in the regional level, the parameters would be broader, for example, to promote conservation of biodiversity in a region. Ensuring the sustainability of environmental resources may require links to other levels of decision-making. These links may be drawn through recommendations for environmental management and planning. For example, recommendations may be made concerning assessments (e.g. Environmental Impact Assessments and Risk Assessments), Environmental Management Systems, Sector-specific Plans and Monitoring Programs. These recommendations should become part of future plans, programs and project formulations (Table 1). 


\begin{tabular}{|c|c|c|c|}
\hline Deforestation & $\begin{array}{l}\text { Avoidance or } \\
\text { minimization of forest } \\
\text { cut/compensatory } \\
\text { plantation }\end{array}$ & $\begin{array}{l}\text { Follow sustainable } \\
\text { harvesting criteria }\end{array}$ & $\begin{array}{l}\text { Ensure that the } \\
\text { removal of forest is } \\
\text { within the sustainable } \\
\text { harvesting limit }\end{array}$ \\
\hline $\begin{array}{l}\text { Displacement of the } \\
\text { local people }\end{array}$ & $\begin{array}{l}\text { Minimization of } \\
\text { displacement and in } \\
\text { case of displacement, } \\
\text { provide proper } \\
\text { resettlement }\end{array}$ & $\begin{array}{l}\text { Follow resettlement } \\
\text { action plan and } \\
\text { government policy }\end{array}$ & $\begin{array}{c}\text { Ensure that all } \\
\text { displaces are resettled }\end{array}$ \\
\hline
\end{tabular}

The Use of Sustainability Framework

The sustainability parameters, objectives, criteria and indicators together form a sustainability framework. This framework can be used in two ways: either to guide the formulation of new plans and programs or to provide a measure against which existing plans and programs can be assessed. The sustainability framework may also be used to evaluate plans or programs which have already been developed. This will assist in determining their sustainability in terms of the context-specific objectives and criteria for sustainability. In this case, the plan or program may be divided into its component parts and evaluated against the sustainability framework.

\section{Conducting the Sea}

For a particular Policy, Plan and program, a series of questions can be raised and can be asked in brainstorming and stakeholders meeting or among planners, decision makers and other relevant persons and institutions and review of already existing information. The following questions are generally asked, but not limited to.

What are the goals and objectives of the policy, plan, or program? do these support relevant environment and sustainable development issues

Goals are broader than objectives and contain general statements; objectives are designed to support to achieve the goal. The Political goals of the ruling party are translated into Policy and supported by a number of objectives. As, for example, improvement of forest cover in a country is a goal to be supported usually by two objectives such as controlling deforestation and enhancing forest plantation activities. So goals and objectives are connected to each other. However, the analysis should be carried out based on the nature of policy, plan and program; if it is broader, the analysis becomes more general but if they are specific such as a health program, it involves a lot of activities that can be identified, so the environmental issues can be scoped out for each.

\section{What are the feasible options for delivering the policy, plan, or program?}

There will be a very few or no options for boarder policy statement; such as "improvement of child health in a country" however there are many ways to do it; so there are options for doing it. At the level of plan and programs, there are possibilities of a numerous options.
"Why do it"? Is a policy;" to improve the child health" has less policy options

"What to do "? Is a Plan has options

"Where to do it"? Is a program has also potions

"How to do it"? Is a method to be adopted at the project level.

What are the significant environmental issues (positive and negative) associated with each of the preferred options?

The options identified are compared, quantified, weighted and scaled. No action option is compared with proposed action options. Adverse impacts and beneficial impacts are quantified and summed up and weighed. Action option with less adverse impacts and with more beneficial ones will be selected as the most preferred option. This can be done with the plan and program level. Example is SEA of Bara forest Management Plan.

\section{Determination of significant}

To determine the significance of the environmental effects, the following criteria can be used: Compliance with standards, Capacity of the environment or institutions to respond to the effects and the level of public concern at the local, national, and international levels about the policy, plan, or program proposal.

\section{Mitigation Measures}

The purpose of this section is to identify measures that will avoid or lessen the negative environmental effects associated with each of the preferred options. There may also be ways to enhance the positive effects resulting from the initiative. Using Electricity example the prices could be set higher for industry clients than for the poor. A natural resource conservation program could be attached with an education initiative in which local residents learn more about their ecosystem.

\section{What is the Most Feasible Policy, Plan, or Program?}

Once the options have been examined, the best option is selected. The most feasible option is one that:

- Most effectively achieves the goals and objectives of the policy, plan, or program.

- Has the least negative environmental effects after mitigation measures have been established and

- Has the least number of unknown environmental effects. 
Sometimes it may be necessary to reject all the options considered and often called choosing the «no go» option.

\section{Monitoring and Auditing}

The sustainability indicators formulated at the assessment stage are useful tools in monitoring in order to examine whether the sustainability criteria are being met, and the parameters given in guidelines are being adhered to. The information obtained from the monitoring and auditing should be useful to provide feedback in the process to promote continual improvement. Monitoring and auditing also allow for adjustment of the sustainability framework and the nature of the plan or program. The monitoring and auditing program could be formulated specially for the plan or program being developed. Typically, the monitoring program will include objectives for monitoring and a description of where, how, when and by whom monitoring has been taken place. Details on the financing of the program should also be included.

\section{The SEA Report}

A final report on SEA should be prepared which should content 2 to 10 pages maximum and should briefly content:

- The outcomes of scanning process

- The assessment of questions of SEA preparation and outcomes of consultation

- Influence of SEA in Policy, Plan and Program formulation and

- Monitoring and reporting provisions

The report should be submitted to the concerned agencies for approval or SEA report should be a part of policy, plan and program document which forms an integral part and that proceed to the cabinet through National Planning Commission for approval. So the responsibility of making SEA should go to those who formulate policy, plan and program. However, it would be appropriate, if the Ministry of Environment Review SEA report.

\section{Review and Decision Making}

The purpose of review is to evaluate the positive and negative aspects of the framework for sustainability and the final draft of the plan or program. The review process must be guided by a term of reference as determined at the beginning of the SEA process. Reviewers can include relevant authorities, specialists and interested and affected parties. The Review is undertaken to ensure that:

a. There is sufficient interest and affected party's involvement;

b. There is sufficient information to make a decision and

c. Legislative, administrative and other requirements have been complied with. In addition, the review should ensure that the SEA was effectively undertaken and the sustainability requirements are incorporated in the plan or program.

\section{Benefits of SEA Application}

The 10 principal benefits of the SEA process are:

1. Provide a systematic review of relevant environmental issues.

2. Improves and refines the basic strategic concepts involved in the PPPs.

3. Achieve a clearer understanding of the potential environmental effects.

4. Enhance the PPP's contribution to the overall goal of environmental sustainability.

5. Create a better balance between environmental, social and economic factors (thus aiding the decision-making process).

6. Simplifying the process of environmental investigations at individual project level and thereby reducing or possibly avoiding the need for project EIA while also accelerating the process of right decision-making.

7. Enhancing the transparency of the PPP making process, and winning public support for preferred options or strategies.

8. Provide guidance on the development of mitigation proposals.

9. Helps to define environmental targets for monitoring purposes and

10. Avoid subsequent delay in PPP implementation.

18. The Spread of Sea and International Practice

Most of the developed countries have adopted SEA and its adoption is rapidly growing geographically and in three broad approaches:

A. SEA has been considered as an extension of EIA; therefore most of EIA methods have been adopted in conducting SEA of PPPs

B. E-test is usually applied in the analysis and evaluation of PPPS as for example in the Netherlands.

C. Environmental Components have been incorporated into a policy appraisal, land use planning and regional planning, as for example in the United Kingdom and in Sweden.

In USA, it is called Programmatic Environmental Impact Statement (PEIS) which is applied under NEPA (1970) and is applied to legislation, regulation enforcement, budget, treaties, convention, plans and policy documents, etc. 
In most of the African countries including South Africa, they already have the system of SEA and legal, Institutional frameworks, methods and techniques have been normally adopted and the practices of examining PPPs in terms of environmental consequences are being conducted. In majority of cases in Africa such as in Ghana, Tanzania, Uganda and in Rwanda, SEA has been used mostly for Poverty Reduction Strategy (PRS), Policy Reform and budget allocation, Education Support program, water Sector Adjustment Plan (Indonesia), Energy and Environment Review (Iran and Egypt) Flood Protection Program (Argentina and Bangladesh), Biodiversity Conservation and Land Use plan (Namibia), Tran boundary Environmental Assessment of Nile Basin (Egypt), Mekong River Commission River Development Plan etc. In addition to these, National Policy, Plan, Programs and Strategies are also being subjected to SEA in all those countries where a system of exists. In South Asia, the system of SEA is not legally binding; however, some studies were being carried out through donors' requirements such as SEA of Thermal Power Policy in Pakistan, SEA of Bara Forest Management Plan and SEA of national Water Plan in Nepal.

Sea and environmental assessment (eia) process, although applied during different phases of the planning cycle, contain some similar assessment activities. The basic distinction in some ways is related to the coverage, including:

1) Assessing alternative PPPs.

2) The additive effects of many small projects that do not require EIA.

3) Induced impacts, where one project stimulates other developments.

4) Synergistic or cumulative impacts, where the impact of several projects exceeds the sum of the individual parts and

5) Global impacts such as biodiversity loss, greenhouse gas emission and climate change issues.

6) Poverty Reduction strategies and Trans boundary cases.

\section{The Need for Strategic Environmental Assessment (SEA) in Nepal}

EIA is being implemented for the projects in Nepal especially as per the schedule 1 and 2 of EPR 1997. To date, nearly 150 EIA reports have been approved by the government and most of them have been implemented; however because of the lack of compliance monitoring, the success of EIA application has not been documented so far in Nepal. Major achievements are seen in the preparation of EIA reports and granting of environmental clearance from the government Ministries for the construction of the project. The project proponent considers that the approval of EIA report is the milestone and do not bother for compliance monitoring and reporting. Preparation and approval of EIA report may take a lot of time and the project proponent usually blames the system for delaying the implementation thereby causing economic loss. This is because;

A. The process is not clear to the EIA report preparers, and the reviewers; so the proponent has to suffer.

B. EIA has to address the issues arising at strategic level also and it creates further confusion.

When PPPs are subjected to environmental examination, most of the strategic issues will be addressed. Therefore, the project level EIA has to focus only to the project specific impacts. So it will be more effective in addressing the issues at the project level and EIA approval system will be quicker and robust. In addition to this, when SEA will be in place, it will have multiple role in addressing the issues of climate change, green economy and the issues of biodiversity. These issues will be addressed when PPPs are subjected to environmental and social review.

It is considered that SEA is direct means for achieving most of the 17 global sustainability goals adopted by UN General Assembly, September 2015. Furthermore Johannesburg World Summit on Sustainable Development emphasized the importance of Strategic Framework for balanced decision making. Paris Declaration on Aid effectiveness 2005, where Ministers and head of development agencies from 100 countries, committed the implementation of SEA in their PPPs and also committed that the donors and their partner countries to develop and apply common approaches for Strategic Environment Assessment at sector and national levels (OECD/DAC 2006).

\section{References}

1. (2000) Environment Canada Strategic Environmental Assessment at Environment Canada: How to Conduct Environmental Assessment of Policy, Plan and Program Proposals.

2. Hong Kong Environmental Protection Department (2000) Examples of Strategic Environmental Assessment in Hong Kong.

3. (1997) OECD/DAC Strategic Environmental Assessment (SEA) in Development Cooperation: State of the Art Review.

4. Sadler B, Verheem R (1996) Strategic Environmental Assessment: Status, Challenges and Future Directions. Ministry of Housing, Spatial Planning and the Environment, the Netherlands.

5. IUCN Strategic Environmental Assessment (1998) Asian Regional Environmental Assessment Program.

6. UN Millennium Ecosystem Assessment (2005) The long term success in meeting all of the MDGs depends on environmental sustainability.

7. Ram K, Steve G, Ananda RJ, Shailendra G, Ajay BM (2013) Environmental Impact Assessment; procedures, methods and practice in South Asian countries. Pokhara University, Nepal. 
Your next submission with Juniper Publishers will reach you the below assets

- Quality Editorial service

- Swift Peer Review

- Reprints availability

- E-prints Service

- Manuscript Podcast for convenient understanding

- Global attainment for your research

- Manuscript accessibility in different formats ( Pdf, E-pub, Full Text, Audio)

- Unceasing customer service

Track the below URL for one-step submission https://juniperpublishers.com/online-submission.php 